\title{
JURANDIR GONÇALVES DE AGUIAR (1948-2007)
}

\author{
RODRIGO NAVES
}

[1] Durante a guerra entre EUA e Espanha, estando em jogo a "independência” de Cuba, o então presidente norte-americano, Mckinley, precisava de alguém que entregasse uma mensagem ao líder dos insurretos cubanos, general Garcia, numa região inóspita da ilha. Aconselhado por seu secretário, o presidente convocou um certo Rowan, que, sem ao menos indagar onde se encontravam os rebeldes, tomou a carta, meteu-a num invólucro que atou ao peito e após três semanas se desincumbia da missão.
Jurandir foi office-boy do Cebrap por 21 anos, de 1978 a 1999, quando se aposentou. Conhecia-o bem, gostava dele e cheguei a ser seu chefe por alguns meses. E por isso não me é nada fácil falar do amigo. Porque além de tudo eu também admirava o Jura como trabalhador, e fica difícil elogiar um grande funcionário sem trazer à lembrança o famoso "Uma mensagem a Garcia", texto escrito por Elbert Hubbard em 1899 e que rapidamente se tornou uma espécie de apologia do empregado sempre pronto a levar a cabo, sem pestanejar, as ordens de seus superiores ${ }^{1}$.

Acontece que de fato Jurandir era bom no que fazia e talvez pudesse ter sido craque em outras atividades, caso houvesse mais alternativas nesta vida. Vai saber. Jura não trazia trabalho para trás. Resolvia tudo. E somente quem nunca trabalhou pode acreditar que a indolência traduz algum vago protesto anticapitalista. Jurandir não fazia apenas as tarefas diretamente relacionadas à instituição. Para facilitar a vida dos pesquisadores, estava autorizado a prestar-lhes serviços, do pagamento de contas a pequenos quebra-galhos.

Ele era de uma honestidade a toda prova - lidava com bastante dinheiro e não me lembro de jamais ter levantado suspeitas e tampouco de ser assaltado, coisa comum na sua profissão. No entanto, não via o menor problema em assinar ele mesmo uma declaração de imposto de renda alheia que o descuido de um de nós levaria a perder um prazo, com as conseqüentes multas e chateações. Malandragem? Não acredito. Era inteligência e discernimento. Afinal, aquele jamegão não mudava em nada o conteúdo do documento - as atuais declarações pela internet o dispensam sem mais - e essa capacidade de avaliar as situações lhe era característica. Talvez minha tolerância com essas informalidades revele mais de mim mesmo que do Jura. Ou do país. Pouco importa isso agora. O que talvez valha a pena sublinharera 
sua admirável capacidade de entender as manhas desse sistema de inúteis dificuldades e de corrigi-lo a partir do que considerava realmente razoável.

Se enganaria porém quem deduzisse de seu profissionalismo um caráter servil. Ao contrário, Jurandir chegava a ser rude de tão brioso. Bastava querer rebaixá-lo para se ver condenado a um tratamento monástico. Ficava a um passo de ser grosso com algumas secretárias e pesquisadores da casa. Grosso e mal-educado. Se não me engano, tinha um distúrbio neurológico que a resistência ao tratamento às vezes agravava e talvez isso explique certos descontroles. Não fora o gajo realmente turrão.

Morava em Franco da Rocha numa casa construída aos poucos, enfrentava diariamente trem e busão, chegava antes de todos ao trabalho e sempre procurava ajudar jovens conhecidos de seu bairro, arrumandolhes emprego (não colocação!) no Cebrap. Um deles, Edimilson, é hoje responsável por toda parte de informática da instituição. Chamava a esposa de "a mulher" e os colegas de trabalho de "cidadão". Nunca o vi reclamar da vida, embora os abusos e folgas de muitos esquerdistas da casa o irritassem. Vivia modestamente e com dignidade.

Mais ou menos seis anos após se aposentar, um câncer de pele na região do nariz começou a castigar-lhe. Quando resolveu tratar-se, foi necessário extirpar-lhe todo o nariz e os gânglios do pescoço, já atingidos. Fui visitá-lo na Santa Casa. No quarto modesto, vendo TV com dois companheiros de internação, apenas levantou o polegar, para dizer que estava tudo bem. Já não podia falar. Grande brasileiro, diria o Luiz Felipe de Alencastro.

Durante as sessões de radioterapia seus sofrimentos pioraram. Seu rosto inchou e as dores aumentavam. Um dia sugeriu ao amigo Edimilson que não queria mais continuar. Jurandir tinha a mania de trocar a ordem de letras e sílabas das palavras. Mariza, também funcionária e nossa querida amiga, tornava-se "zarima", eu era "godriro" e os filhos-da-puta "lhafi tapu". Infelizmente, com o câncer não foi possível inverter a ordem das coisas. EJurandir preferiu entregar os pontos. Morreu no dia 17 de fevereiro bem cedo, sábado de Carnaval. Nem então incomodou os amigos. A folia ainda estava para começar, as cidades vazias, o trânsito livre, os amigos com tempo para se despedir.

Vamos sentir sua tafal, dãodaci. 